\begin{tabular}{|l|l|l|}
\hline \multicolumn{2}{|c|}{ PublisherInfo } \\
\hline \hline PublisherName & $:$ & BioMed Central \\
\hline \hline PublisherLocation & $:$ & London \\
\hline \hline PublisherImprintName & $:$ & BioMed Central \\
\hline \hline
\end{tabular}

\title{
A progesterone receptor polymorphism (PROGINS) and breast cancer risk
}

\begin{tabular}{|l|l|l||}
\hline \multicolumn{2}{|c|}{ ArticleInfo } \\
\hline \hline ArticleID & $:$ & 3719 \\
\hline \hline ArticleDOI & $:$ & $10.1186 /$ bcr-2000-66682 \\
\hline \hline ArticleCitationID & $:$ & 66682 \\
\hline \hline ArticleSequenceNumber & $:$ & 85 \\
\hline \hline ArticleCategory & $:$ & Paper Report \\
\hline \hline ArticleFirstPage & $:$ & 1 \\
\hline \hline ArticleLastPage & $:$ & 4 \\
\hline \hline & $:$ & RegistrationDate : 2000-6-14 \\
\hline ArticleHistory & $:$ & OnlineDate \\
\hline \hline ArticleCopyright & $:$ & Current Science Ltd2000-6-14 \\
\hline \hline ArticleGrants & $:$ & \\
\hline \hline ArticleContext & $:$ & 1305822 \\
\hline \hline
\end{tabular}


Catherine Healey, ${ }^{\text {Affl }}$

Affl Department of Oncology, University of Cambridge, UK

\section{Keywords}

Association study, progesterone receptor, PROGINS

\section{Introduction}

The human progesterone receptor (HPR) gene belongs to the steroid-thyroid-retinoic acid receptor superfamily of transcription factors. The HPR-A isoform is thought to repress activation by the oestrogen receptor and the HPR-B isoform. A $306 \mathrm{bp}$ Alu insertion (PROGINS) has been identified in exon 7 of the gene. This polymorphism is in linkage disequilibrium with a mutation in exon 4 that causes an amino acid substitution in the hinge region of the receptor. Several studies, from different countries, have been unable to show a significant association of PROGINS with breast or ovarian cancer.

\section{Aims}

To investigate whether there is an association between PROGINS and breast cancer in a German population.

\section{Comments}

As the search for low penetrance breast cancer genes progresses, the need for large studies which have the power to detect significant associations is becoming more apparent. This is particularly true for polymorphisms with rare allele frequencies, such as PROGINS. The population based, case-control study reported here is well designed and large enough to reveal a protective association between breast cancer and the PROGINS variant of the human progesterone receptor gene in a German population. This is predominantly a study of premenopausal women and further investigations are needed to determine the effect of the progesterone receptor on breast cancer risk in postmenopausal women. Previously, three small studies looked at PROGINS and breast cancer risk, but none of these showed a significant association. A recent paper (Dunning et al, Cancer Epidemiol Biomarkers and Prev 1999, 8:843-854) 
has reported that the combined results of these three studies do show a significant protective effect for the rare homozygotes (OR (odds ratio) 0.41 [95\%CI: $0.15-0.95]$ ) and this will undoubtedly be strengthened by the addition of this present study.It is worth noting that; although the protective effect of the progesterone receptor has been highlighted, the fact that this is associated with the rare allele actually means that the majority of women are at increased risk.

\section{Methods}

The study involved 577 incident breast cancer cases, diagnosed before the age of 51 years, and 579 age- and residence-matched controls derived from two Caucasian populations in Germany.PROGINS was analysed using PCR amplification and gel electrophoresis. The A1 allele gave a $175 \mathrm{bp}$ fragment and the A2 (T2) (PROGINS) allele gave a 481 bp fragment.

\section{Results}

The frequency of the PROGINS allele was significantly lower in the breast cancer cases $(0.12)$ than in the controls (0.16) $P=0.01$. Both the cases and controls were in Hardy-Weinberg equilibrium.Carriers of the A2 allele had a decreased risk of breast cancer (OR 0.76 [95\%CI: 0.58-1.00]). The OR decreased with increasing numbers of A2 allele in the three genotypes, Pfor trend $<0.01$, suggesting a dose effect. ORs for the heterozygous and homozygous A2 genotypes were 0.82 (95\%CI: 0.62-1.08) and 0.27 (95\%CI: 0.10-0.74) respectively. There was no effect on disease risk when an interaction of the PROGINS genotype and age at menarche, parity or duration of breastfeeding was explored.

\section{Discussion}

In this well designed study examining a possible association of the PROGINS allele with breast cancer incidence, a reduced risk of the disease was observed in women who were carriers of the A2 allele. A significant trend of declining risk was observed with increasing numbers of A2 allele and there is a suggestion that this effect is confined to premenopausal women. Several other studies have been unable to show a significant association of PROGINS with breast or ovarian cancer. The authors suggest study design as a possible reason for this lack of association; however, in one study on an Irish population, there was a deficit of A2 homozygotes in the cases $(P<0.05)$, which is compatible with the observations from this present study.The HPR-A PROGINS allele has been shown to have increased transcriptional activity and stability. The authors suggest that this may lead to a more efficient repression of the oestrogen receptor, hence decreasing breast cancer risk.More functional studies need to be done to determine how the polymorphic HPR gene may modify the risk of breast cancer at the molecular level. 


\section{Additional information}

The exon 4 amino acid change, which is in linkage disequilibrium with the PROGINS allele, is more likely to be the functional variant. Hence, this may be the more obvious polymorphism to genotype in future association studies on the progesterone receptor.

\section{References}

1. Wang-Gohrke S, Chang-Claude J, Becher H, Kieback DG, Runnebaum IB: Progesterone receptor gene polymorphism is associated with decreased risk for breast cancer by age 50. Cancer Res. 2000, 60: 2348-2350.

This PDF file was created after publication. 